\title{
The Buccalin-related Neuropeptides: Isolation and Characterization of an Aplysia cDNA Clone Encoding a Family of Peptide Cotransmitters
}

\author{
M. W. Miller, ${ }^{1,2,3, a}$ S. Beushausen, ${ }^{4}$ E. C. Cropper, ${ }^{2}$ K. Eisinger, ${ }^{3}$ S. Stamm, ${ }^{3}$ F. S. Vilim, ${ }^{1}$ A. Vitek, ${ }^{2}$ A. Zajc, ${ }^{3}$ \\ I. Kupfermann, ${ }^{1,5}$ J. Brosius, ${ }^{3}$ and K. R. Weiss ${ }^{2,3}$ \\ ${ }^{1}$ Center for Neurobiology and Behavior, The New York State Psychiatric Institute, New York, New York 10032, \\ ${ }^{2}$ Department of Physiology and Biophysics and ${ }^{3}$ Fishberg Research Center in Neurobiology, Mount Sinai School of \\ Medicine, New York, New York 10029, ${ }^{4}$ Laboratory of Neurobiology, NINDS, Bethesda, Maryland 20892, and ${ }^{5}$ Department \\ of Physiology and Cellular Biophysics, Columbia University, College of Physicians and Surgeons, New York, New York \\ 10032
}

The buccalin-related peptides, buccalin $A$ and buccalin $B$, are members of a family of cotransmitters that modulate neuromuscular transmission in Aplysia. In this study, a third buccalin-related peptide, buccalin $C$, was purified from neuronal elements in the accessory radula closer, a muscle involved in the animal's feeding behavior. Oligonucleotide probes based upon the amino acid sequence of buccalin $\mathrm{C}$ were used to Isolate cDNA clones that encode a buccalin precursor polypeptide. The buccalin precursor contains 19 distinct buccalin-related peptides, several of which are present in multiple copies. The buccalin gene appears to be present in a single copy, with one allele containing a small insert. Expression of this gene occurs in a tissue-specific manner and mRNA transcripts are abundant within neurons in the Aplysia CNS. This large family of neuropeptides may exert extraordinarily complex modulatory actions at synapses where they serve as cotransmitters.

IKey words: neuropeptide, cotransmitter, precursor, Aplysia californica, buccalin, neuromodulator, peptide family, polypeptide, mollusk, invertebrate]

Biologically active peptides often coexist in neurons with "classical" transmitter substances where they can act to modulate the efficacy or temporal characteristics of synaptic transmission (Jan and Jan, 1983; Lundberg and Hökfelt, 1986; Campbell, 1987; Kupfermann, 1991). The large identifiable neurons present in certain invertebrates have proved to be useful for the identification of neuropeptide cotransmitters and for studying properties of cotransmitter signaling (Adams and O'Shea, 1983; Bishop et al., 1984, 1987; Calabrese, 1989).

In Aplysia, several neuropeptides are present in identified

\footnotetext{
Received Aug. 28, 1992; revised Jan. 13, 1993; accepted Jan. 20, 1993.

We thank Robert S. Woolley for assistance with the figures and Drs. Marc Glucksman, William C. Probst, and Wayne Sossin for reading earlier versions of the manuscript. This study was supported by USPHS Grants MH36730 and GM32099, and funds from the Whitehall Foundation and the McKnight Endowment Fund for Neuroscience.

Correspondence should be addressed to Dr. Mark W. Miller, c/o Dr. K. R. Weiss, Department of Physiology and Biophysics, Box 1218, Mount Sinai School of Medicine, 1 Gustave Levy Place, New York, NY 10029.

a Present address: Institute of Neurobiology, University of Puerto Rico, Boulevard del Valle 201, San Juan, Puerto Rico 00901.

Copyright (c) 1993 Society for Neuroscience $0270-6474 / 93 / 133346-12 \$ 05.00 / 0$
}

neurons that comprise the circuits underlying feeding behavior (Lloyd et al., 1985, 1987, 1988; Ono, 1986; Cropper et al., 1987a,b, 1988, 1990b; Church and Lloyd, 1991). One such neuropeptide, buccalin $\mathrm{A}$, was originally sequenced following purification from neuronal elements in the accessory radula closer (ARC) muscle (Cropper et al., 1988). Buccalin A is synthesized in both of the motor neurons (B15 and B16) that innervate the ARC (Cropper et al., 1988, 1990b; Church and Lloyd, 1991), where it is colocalized with the conventional neurotransmitter $\mathrm{ACh}$ (Cohen et al., 1978) as well as additional neuropeptides (Cropper et al., 1987a,b). It is transported via fast axonal transport to the muscle (Lloyd, 1988), where it is present in densecore vesicles in neuronal varicosities and is released upon firing of the motor neuron (Cropper et al., 1990b; Vilim et al., 1990, 1991, 1992). Exogenous application of buccalin A produces a depression of ARC contractions evoked by stimulation of B15 or B16 but has no effect on contractions produced by direct application of $\mathrm{ACh}$ to the muscle. It was therefore proposed that buccalin $A$ serves as a modulatory cotransmitter that acts by decreasing the release of $\mathrm{ACh}$ from neuronal terminals in the muscle (Cropper et al., 1988, 1990a).

Histochemical and physiological experiments indicate that the modulatory actions of buccalin $\mathrm{A}$ are not limited to the Aplysia feeding system. Buccalin-like immunoreactive material is present in specific neurons in each of the major central ganglia (Miller et al., 1992). Exogenously applied buccalin A has modulatory effects on mechanosensory neurons in the cerebral and pleural ganglia (Raymond et al., 1989; Rosen et al., 1989). The presence of varicosities containing buccalin-like immunoreactivity in tissues of the cardiovascular, reproductive, and digestive systems suggests that buccalin may have a variety of actions in the periphery.

Recent studies indicate that buccalin A belongs to a family of related peptides that may be widely distributed among mollusks. A peptide with substantial homology to buccalin A was isolated from the central ganglia of the prosobranch Fusinus ferrugineus (Kobayashi and Muneoka, 1990). This peptide (termed Fusinus buccalin) and buccalin A both depress contractions of the radula retractor muscle of Fusinus, indicating that the buccalin-related peptides may serve similar functions in different species (Kobayashi and Muneoka, 1990). Buccalinlike immunoreactive material is also present in the genital gan- 
Table 1. Protocol for purification of buccalin $\mathrm{C}$

\begin{tabular}{|c|c|c|c|c|}
\hline Stcp ${ }^{\prime}$ & Column $^{h}$ & Solvent A & Solvent B & Gradient $^{c}$ \\
\hline 1 & $\begin{array}{c}\text { Zorbax } \\
\text { C8 }\end{array}$ & $\begin{array}{l}0.01 \mathrm{M} \mathrm{HFBA} \\
\mathrm{H}_{2} \mathrm{O}\end{array}$ & $\begin{array}{l}0.01 \text { м HFBA, } \\
\mathrm{CH}_{3} \mathrm{Cn}\end{array}$ & $\begin{array}{l}20-35 \% \mathrm{~B} \\
\text { in } 120 \mathrm{~min}\end{array}$ \\
\hline 2 & $\begin{array}{l}\text { Zorbax } \\
\text { C8 }\end{array}$ & $\begin{array}{c}0.01 \mathrm{M} \text { TFA, } \\
\mathrm{H}_{2} \mathrm{O}\end{array}$ & $\begin{array}{c}0.01 \mathrm{M} \text { TFA, } \\
\mathrm{CH}_{3} \mathrm{CN}\end{array}$ & $\begin{array}{l}15-35 \% \mathrm{~B} \\
\text { in } 160 \mathrm{~min}\end{array}$ \\
\hline 3 & $\begin{array}{r}\text { Aquapore } \\
\text { RP-300 }\end{array}$ & $\begin{array}{l}0.1 \mathrm{M} \text { TEAA, } \\
\mathrm{H}_{2} \mathrm{O}\end{array}$ & $\begin{array}{l}0.1 \mathrm{~m} \text { TEAA, } \\
80 \% \mathrm{CH}_{3} \mathrm{CN}, \\
20 \% \mathrm{H}_{2} \mathrm{O}\end{array}$ & $\begin{array}{l}5-27 \% \mathrm{~B} \\
\text { in } 88 \mathrm{~min}\end{array}$ \\
\hline 4 & $\begin{array}{r}\text { Aquapore } \\
\text { RP-300 }\end{array}$ & $\begin{array}{l}0.1 \text { м HFBA, } \\
\quad \mathrm{H}_{2} \mathrm{O}\end{array}$ & $\begin{array}{l}0.01 \text { м HFBA, } \\
\mathrm{CH}_{3} \mathrm{CN}\end{array}$ & $\begin{array}{l}20-25 \% \mathrm{~B} \\
\text { in } 20 \mathrm{~min} \text {, } \\
25-29 \% \mathrm{~B} \\
\text { in } 32 \mathrm{~min}\end{array}$ \\
\hline 5 & $\begin{array}{r}\text { Aquapore } \\
\text { RP-300 }\end{array}$ & $\begin{array}{l}0.01 \text { м TFA, } \\
\mathrm{H}_{2} \mathrm{O}\end{array}$ & $\begin{array}{c}0.01 \text { м TFA } \\
\mathrm{CH}_{3} \mathrm{CN}\end{array}$ & $\begin{array}{l}15-45 \% \mathrm{~B} \\
\text { in } 30 \mathrm{~min}\end{array}$ \\
\hline
\end{tabular}

HFBA, heptafluorobutyric acid; TFA, trifluoroacetic acid; TEAA, triethylamine acetate.

${ }^{a}$ Steps 1, 2, 4, and 5: $\mathrm{pH} 2.0$; Step 3: $\mathrm{pH}$ 5.5.

${ }^{b}$ Both columns: $4.6 \times 250 \mathrm{~mm}$.

' All gradients were linear, and flow rate in each case was $1 \mathrm{ml} / \mathrm{min}$. Fractions were collected every $30 \mathrm{sec}$.

glion of the pulmonate snail Melampus bidentatus (Moffett, 1990). Recently, a structurally related peptide, buccalin B, was purified from the ARC muscle of Aplysia and found to exert modulatory actions similar to those of buccalin A (Weiss et al., 1988.

In this study, a third buccalin-related peptide was purified from the ARC and a molecular cloning approach was used to characterize further the buccalin family of neuropeptides. The sequence of cDNA clones encoding a buccalin precursor indicates that this family is composed of an extraordinarily large group of neuropeptides that are derived from a single polypeptide. The possible presence of up to 19 distinct but related peptides, several of which have been shown to modulate synaptic transmission in the ARC muscle, confers the potential for considerable complexity at synapses where members of the buccalin family act as cotransmitters.

Some of these results have been reported previously in abstract form (Miller et al., 1989).

\section{Materials and Methods}

Purification of buccalin C. Buccalin C was purified from the $100 \mathrm{gm}$ of ARC muscle (material used in the purification of myomodulin B; see Cropper et al., 1991). Briefly, muscles were heated to $100^{\circ} \mathrm{C}$ in $0.1 \mathrm{M}$ acetic acid (final tissue concentration, $0.1 \mathrm{~g} / \mathrm{ml}$ ), homogenized, heated again, and centrifuged at $7000 \times g$. The supernatant was applied to C-18 cartridges (Sep-Paks, Waters) and peptides were eluted with 0.01 M trifluoroacetic acid in $66 \%$ acetonitrile $\left(\mathrm{CH}_{3} \mathrm{CN}\right), 34 \% \mathrm{H}_{2} \mathrm{O}$. The eluate was subjected to five steps (Table 1) of sequential reverse-phase highpressure liquid chromatography (RP-HPLC). RP-HPLC fractions were identified for subsequent chromatography by their bioactivity on the ARC muscle. Bioactive fractions decreased the size of muscle contractions elicited by stimulation of either of the two motor neurons of the ARC (see Cropper et al., 1987a, 1988). Purified material was subjected to automated Edman degradation on an Applied Biosystems 470A gasphase sequencer at the Protein Chemistry Core Facility of Columbia University. Phenylthiohydantoin amino acids were analyzed on an Applied Biosystems 120A PTH analyzer.

Isolation and purification of $c D N A$ clones. Two 64-fold degenerate 20-mer oligodeoxynucleotide probes were derived from the amino acid sequence of buccalin C: GTAAANCCG/ATAG/ATGG/ATCG/AAA and GTGAANCCG/ATAG/ATGG/ATCG/AAA (N: mixture of four nucleotides direction $5^{\prime} \rightarrow 3^{\prime}$ ). The oligonucleotides were end labeled with ${ }^{32} \mathrm{P}-\gamma$-ATP and used as probes to screen $5 \times 10^{5}$ pfu from a buccal ganglion cDNA library (provided by R. Scheller, Stanford University). Hybridization solution consisted of $5 \times$ saline-sodium citrate (SSC), 50 mм $\mathrm{NaP}_{\mathrm{i}}(\mathrm{pH} 6.8), 1 \mathrm{~mm}$ sodium pyrophosphate, $5 \times$ Denhardt's solution [Denhardt's solution: $0.2 \%$ Ficoll, $0.2 \%$ bovine serum albumin (BSA), $0.2 \%$ polyvinylpyrrolidone], $20 \%$ formamide, and $100 \mu \mathrm{g} / \mathrm{ml}$ denatured salmon sperm DNA. Filters were hybridized overnight at $40^{\circ} \mathrm{C}$ and washed $(3 \times 20 \mathrm{~min})$ in $1 \times \mathrm{SSC}, 1 \% \mathrm{SDS}$ at $42^{\circ} \mathrm{C}$. A single candidate clone was purified through a tertiary screen; its insert [1.0 kilobase (kb)] was subcloned into the plasmid vector pBluescript $\mathrm{KS}(-)$ (Stratagene), and sequenced on both strands using the Sequenase (U.S. Biochemicals) system. This clone is denoted pBU01 in Figure 2.

A nondegenerate 30 -mer oligonucleotide probe complementary to sequence near the 5' end of BU01 (BUC30 in Fig. 2: 5'TATCCATACCACGCTTTCCTAGACCAGGGG) was used to screen a randomly primed nervous system cDNA library (Beushausen et al., 1988) in order to isolate full-length clones. Sixty positive clones were isolated from 5 $\times 10^{5}$ pfu. Twelve were randomly chosen, subcloned into the plasmid vector pSL300 (Brosius, 1989), and subjected to restriction enzyme analysis. Several clones, for example, pBU12 and pBU13 in Figure 2, were sequenced on both strands.

Genomic Southern blot analysis. Genomic DNA, isolated from the ovotestis of a single Aplysia specimen, was digested to completion (overnight) with single restriction enzymes or pairs, size fractionated on a $0.75 \%$ agarose gel $(10 \mu \mathrm{g} / \mathrm{lane})$, denatured, and electroblotted onto GeneScreen nylon membrane (New England Nuclear). The filter was prehybridized at $60^{\circ} \mathrm{C}$ for $3 \mathrm{hr}$ in $6 \times \mathrm{SSC}, 10 \mathrm{~mm}$ EDTA, $5 \times$ Denhardt's solution (see above), $0.5 \%$ SDS, $10 \%$ formamide, and $100 \mu \mathrm{g} / \mathrm{ml}$ heat denatured salmon sperm DNA. The probes (either buccalin clone pBU12, the $1.2 \mathrm{~kb}$ purified insert DNA from pBU12, or a $1.4 \mathrm{~kb} \mathrm{NcoI-BglII}$ fragment of pBU13; see Fig. 2) were ${ }^{32}$ P-labeled by nick translation (Bethesda Research Laboratories) or by random priming (Prime-It, Stratagene, La Jolla, CA), heat-denatured $\left(95^{\circ}, 5 \mathrm{~min}\right)$, and hybridized overnight at $68^{\circ} \mathrm{C}$. Filters were washed $2 \times 30 \mathrm{~min}$ in $1 \times \mathrm{SSC}, 0.5 \% \mathrm{SDS}$ at $65^{\circ} \mathrm{C}$ before autoradiography.

Reverse transcription/PCR. Total RNA $(1 \mu \mathrm{g})$ extracted from Aplysia nervous system, ovotestis, and heart tissue was reverse transcribed following the manufacturer's protocol (GeneAmp, Perkin Elmer Cetus). The oligonucleotides PCR5 and MM025 (see Fig. 2) were used as primers for PCR $\left(2 \mathrm{~min}\right.$ at $95^{\circ} \mathrm{C}$ for 1 cycle; $1 \mathrm{~min}$ at $95^{\circ} \mathrm{C}, 1 \mathrm{~min}$ at $60^{\circ} \mathrm{C}$ for 35 cycles; $7 \mathrm{~min}$ at $35^{\circ} \mathrm{C}$ for 1 cycle). PCR products were shown to originate from buccalin mRNA by Southern analysis, using an endlabeled internal oligonucleotide (BUC30; see Fig. 2) as a probe.

In situ hybridization. The protocols of Angerer et al. (1987) and Tiedge (1991) were followed. A ${ }^{35}$ S-labeled RNA probe was generated from a 390 base pair (bp) subcloned EcoRI-XhoI fragment from the coding region of the buccalin cDNA (corresponding to the bases 649-1039 of Fig. 3). Single-stranded RNA probes were produced following standard protocols (Promega) using T3 (antisense) or T7 (sense) RNA polymerase 


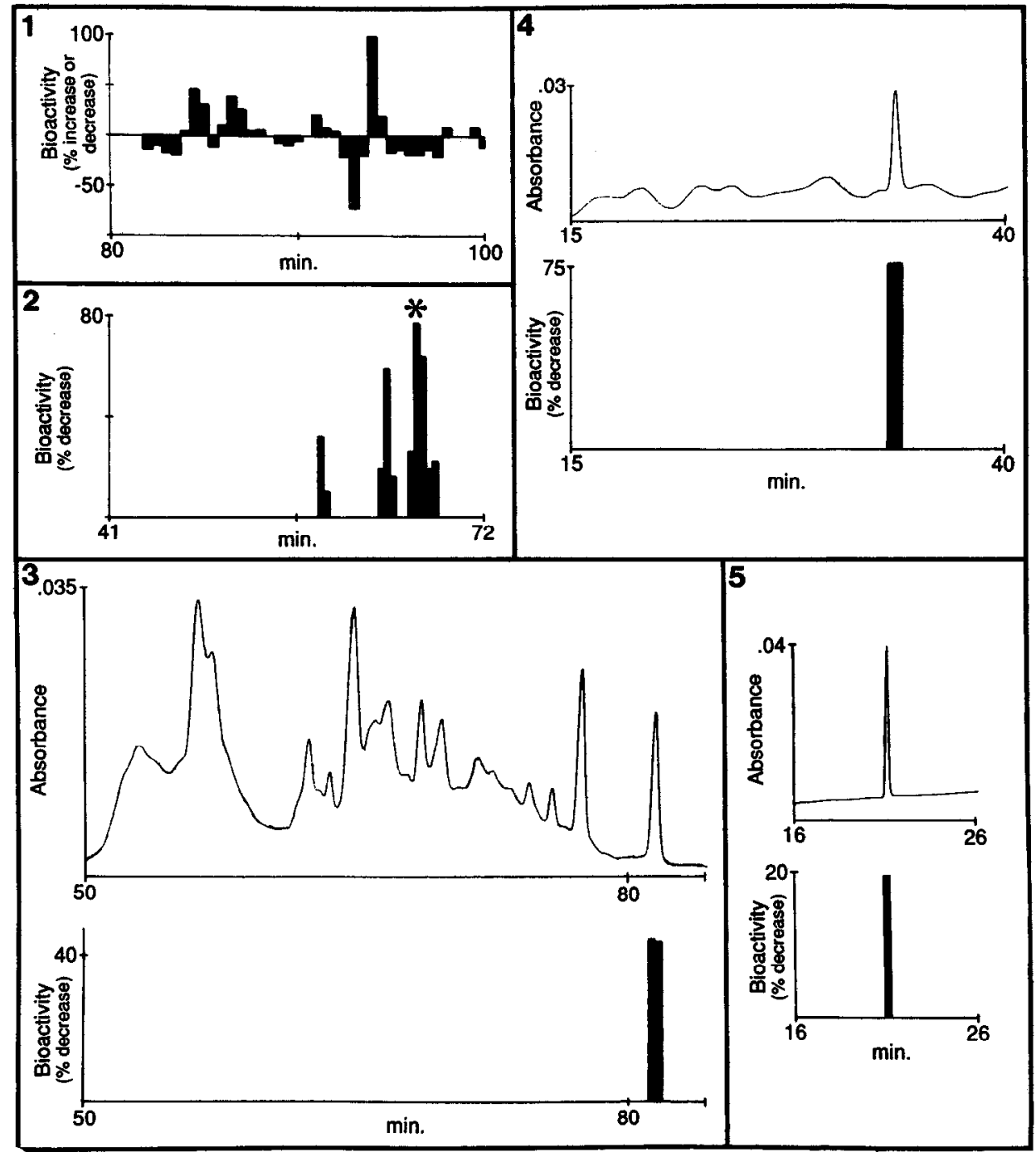

Figure 1. Purification of buccalin C. Five sequential RP-HPLC passes (Table 1) were used to purify buccalin C from ARC muscles. Chromatographic conditions were progressively altered either by changing the hydrophobic ion pairing reagent included in the acetonitrile/ $\mathrm{H}_{2} \mathrm{O}$ gradient or by changing the column. Fractions containing active peptides were identified by assay on the ARC muscle (see Materials and Methods). Bioactivity is expressed as percentage increase or decrease in the amplitude of muscle contractions elicited by stimulation of motor neuron B15 or B16 3 min after fraction application directly on the ARC muscle. 1 , Some of the bioactive fractions that eluted between 80 and 100 min increased contraction size while others decreased it, suggesting that a mixture of peptides was eluting in this region, and that this mixture had not been effectively separated by the chromatographic conditions used. 2, Rechromatography of the 80-100 min region of bioactivity in the presence of $0.1 \mathrm{~m}$ trifluoroacetic acid (Table 1, step 2) yielded six discrete peaks of RP-HPLC fractions that decreased contraction size, and three peaks that increased it (not all shown). Note that the ordinate in this and subsequent panels expresses the percentage decrease of evoked contraction magnitude. Rechromatography of the peak indicated by the asterisk in 2 is shown in 3-5.3, Rechromatography of the peak indicated by the asterisk in 2 (Table 1, step 3) in the presence of $0.1 \mathrm{M}$ triethylamine acetate yielded several discrete UV-absorbent peaks (top), one of which was bioactive (bottom). 4, Rechromatography of the bioactive peak shown in 3 (Table 1, step 4) in $0.01 \mathrm{M}$ heptafluorobutyric acid yielded one UV-absorbent (top), bioactive (bottom) peak. 5 . The final purification step (Table 1, step 5), performed in the presence of $0.01 \mathrm{M}$ trifluoroacetic acid, yielded a single optically pure UV-absorbent (top), bioactive (bottom) peak.

in transcription reactions with linearized templates. Sections (15-20 $\mu \mathrm{m})$ of the ring ganglia were collected on silanated slides (Clayton and Alvarez-Buylla, 1989), cross-linked using UV light (Tiedge, 1991), treated with proteinase $\mathrm{K}(10 \mu \mathrm{g} / \mathrm{ml}, 5 \mathrm{~min})$, and subjected to postfixation (4\% paraformaldehyde, $5 \mathrm{~min})$. Prehybridization (1-2 hr) and hybridization $\left(3-5 \times 10^{6} \mathrm{cpm} / \mathrm{ml}\right.$ of probe, $\left.12-18 \mathrm{hr}\right)$ were carried out at $50^{\circ} \mathrm{C}$ in a solution containing $10 \mathrm{~mm}$ Tris- $\mathrm{HCl}, 0.6 \mathrm{M} \mathrm{NaCl}, 1 \mathrm{~mm}$ EDTA, $10 \mathrm{~mm}$ dithiothreitol, $0.1 \% \mathrm{BSA}, 0.02 \%$ Ficoll, $0.02 \%$ polyvinylpyrrolidone, $10 \mu \mathrm{g} / \mathrm{ml}$ salmon sperm DNA, $50 \mu \mathrm{g} / \mathrm{ml}$ yeast total RNA, $50 \mu \mathrm{g} /$ $\mathrm{ml}$ Escherichia coli transfer RNA, 50\% formamide, and $10 \%$ dextran sulfate. Tissues were washed in $2 \times \mathrm{SSC}$ at $45^{\circ} \mathrm{C}$ for $1 \mathrm{hr}$, subjected to an RNase digestion $(30 \mu \mathrm{g} / \mathrm{ml}$ RNase $\mathrm{A})$ at $37^{\circ} \mathrm{C}$ for $1 \mathrm{hr}$, and washed in $0.1 \times \mathrm{SSC}, 0.05 \%$ sodium pyrophosphate, $14 \mathrm{~mm} \beta$-mercaptoethanol for $3 \mathrm{hr}$ at $55^{\circ} \mathrm{C}$. Following an overnight wash in this solution at room temperature, sections were dehydrated, dried under vacuum, and ex- posed to X-ray film. Kodak reagents (emulsion, developer, fixer) were used to produce microscopic visualization of the hybrids, and sections were photographed with a Leitz Orthoplan microscope.

\section{Results}

Purification and sequencing of buccalin $C$

Buccalin $C$ was purified from material extracted from the ARC neuromuscular system using five stages of sequential RP-HPLC (Table 1). Material was identified for rechromatography by its bioactivity in the ARC muscle (Fig. 1). Fractions containing buccalin $\mathrm{C}$ decreased the size of muscle contractions elicited by stimulation of either of the two motor neurons of the ARC (B15 


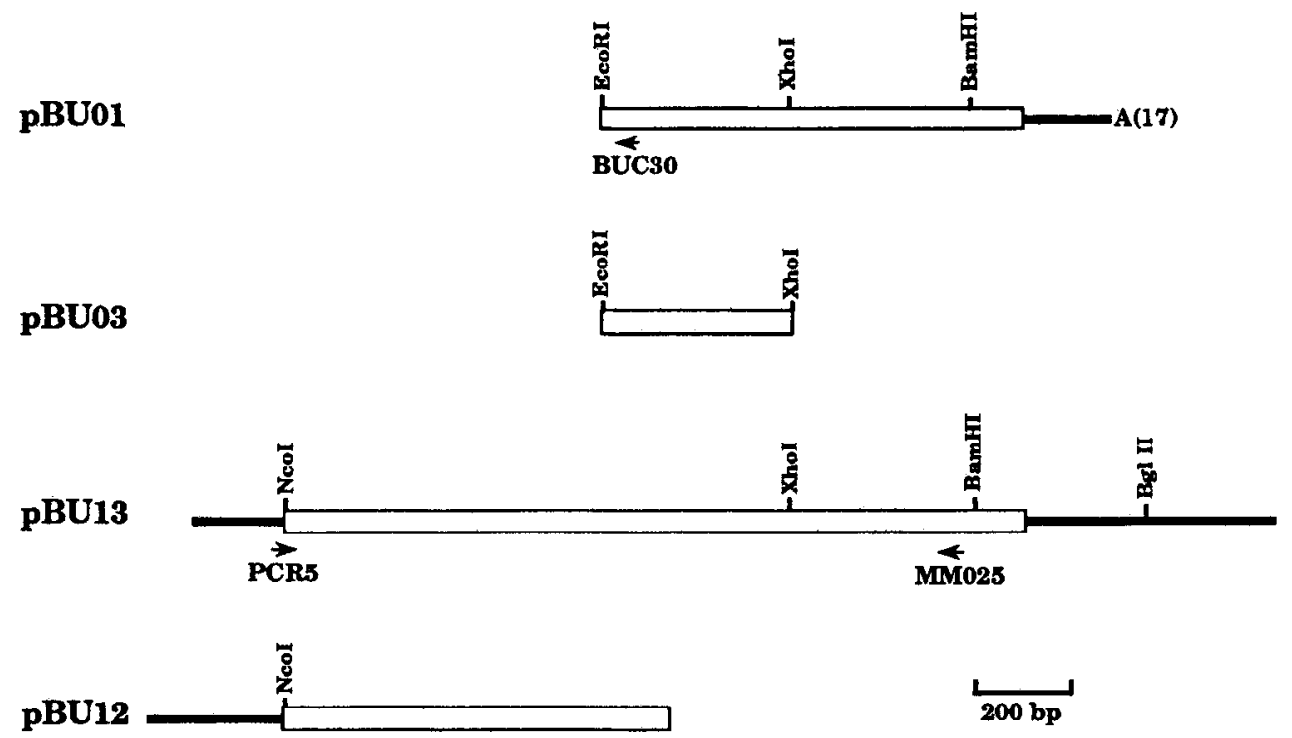

Figure 2. Schematic representation of buccalin clones. Coding region is shown as open rectangle and noncoding regions are solid bars. pBU01, A $1 \mathrm{~kb}$ clone isolated from buccal ganglion cDNA library. $B U C 30$, oligonucleotide probe (30-mer), complementary to a $5^{\prime}$ region of BU01, that was used to screen a nervous system cDNA library. $p B U 03$, EcoRI-XhoI fragment of pBU01 that was used as probe for in situ hybridization (Fig. 7B). $p B U 13$, Longest fully characterized nervous system cDNA clone (Fig. 3). PCR5, MM025, oligonucleotide primers used in reverse transcription/PCR experiments (Fig. $7 A$ ). Arrows denote oligonucleotides and their direction $\left(5^{\prime}\right.$ to $\left.3^{\prime}\right)$. pBU12, Nervous system cDNA clone, containing farthest characterized $5^{\prime}$ sequence (bracketed in Fig. 3). This clone was used as probe for genomic Southern experiments (Fig. 5).

and B16). Gas-phase sequence analysis of purified material yielded the following sequence and amounts (in picomoles) of amino acids: Gly(168)-Phe(123)-Asp(77)-His(42)-Tyr(115)Gly(88)-Phe(95)-Thr(10)-Gly(52)-Gly(58)-Ile(10). This new neuropeptide was termed buccalin $\mathrm{C}$ since it is structurally homologous to two previously characterized peptides, buccalin A and buccalin B (Cropper et al., 1988; Weiss et al., 1988).

\section{Isolation of cDNA clones}

Screening a buccal ganglion cDNA library with two degenerate oligonucleotide probes designed from the amino acid sequence of buccalin $\mathrm{C}$ resulted in the isolation of a single $1 \mathrm{~kb}$ candidate clone (pBU01, Fig. 2). The nucleotide sequence of the mRNA sequence corresponding to pBU01 includes a consensus polyadenylation signal AAUAAA (Proudfoot and Brownlee, 1976) and a polyA tail 17 nucleotides in length. Using these cues to define the strand and direction of coding, the sequence of pBUOI was found to encode a polypeptide containing buccalin $\mathrm{C}$ and several additional buccalin-related peptides. This clone, however, appeared to be incomplete, lacking a $5^{\prime}$ untranslated region and a domain corresponding to a signal sequence. A nondegenerate oligonucleotide probe (BUC30, Fig. 2) complementary to the coding sequence near the $5^{\prime}$ end of pBU01 was then used to screen a nervous system cDNA library at moderatc stringency. This screen yielded 60 candidate clones. Restriction mapping and sequencing of these clones showed that they overlapped with pBU01 and extended to varying lengths in the $5^{\prime}$ direction. Several clones, for example, pBU13 (Figs. 2, 3), extended in both the $5^{\prime}$ and $3^{\prime}$ directions.

The nucleotide sequence of pBU13 (2194 bp) contains an open reading frame that predicts a buccalin precursor molecule 505 amino acids in length (Fig. 3, amino acid sequence above nucleotide sequence). The assigned initiator methionine residue of the corresponding mRNA is located within a consensus sequence (CACCAUGG) for eukaryotic initiation sites (Kozak, 1983). It is preceded by at least 189 nucleotides in which no AUG codons are found and in which multiple termination codons are present in all three reading frames. The sequence of another clone (Fig. 2, pBU12) indicates that the $5^{\prime}$ untranslated region extends at least an additional 81 nucleotides (bracketed in Fig. 3), but this sequence has not been confirmed on additional clones.

The open reading frame of pBU13 is terminated by a UGA stop codon that is followed by 477 nucleotides of 3 ' untranslated sequence. Two consensus polyadenylation signals (both AAUAAA) are present beginning at positions 1638 and 1830 (boldface in Fig. 3). Multiple polyadenylation signals have been noted in the genes of several regulatory peptides in Aplysia (Nambu ct al., 1983; Taussig and Scheller, 1986; Wickham and DesGroseillers, 1991). Of five clones sequenced in this region, only pBU01 has a polyA tail (17 adenosines) that begins at a position corresponding to nucleotide 1665 of pBU13 (underlined in Fig. 3). This observation could reflect differences in the methodologies used in the construction of the libraries from which these clones were isolated; pBU01 was purified from a library in which an oligo-dT primer was used to direct firststrand synthesis while all other clones were isolated from a randomly primed library. If, however, the alternative polyadenylation sites are used to generate multiple mRNAs, variation of the $3^{\prime}$ untranslated regions may affect buccalin gene expression via the regulation of mRNA stability or translation (see Manley, 1988).

The most 3 ' end of pBU 13 consists of a tract approximately 70 nucleotides in length that includes three ACAT sequences repeated in tandem (Fig. 3, positions 1948-1960) and ends with 14 CA repeats. Similar motifs are present in the $3^{\prime}$ untranslated regions of several other Aplysia neuropeptide genes, but their significance or role has not been determined (Nambu et al., 1983; Taussig et al., 1984; Mahon et al., 1985; Shymala et al., 1986).

\section{Multiple peptides may be derived from the buccalin precursor}

The initiator methionine of the buccalin precursor is followed by a highly charged region of seven amino acids that includes three histidine and two arginine residues. This sequence is followed by 11 uncharged amino acids, including one isoleucine, one valine, one alanine, and five leucines (underlined in Fig. 3). The signal sequence (or signal peptide), which serves to direct translocation of nascent secretory proteins into the lumen of the endoplasmic reticulum (Blobel and Dobberstein, 1975), typically contains a positively charged amino-terminal $\mathrm{N}$-region and 


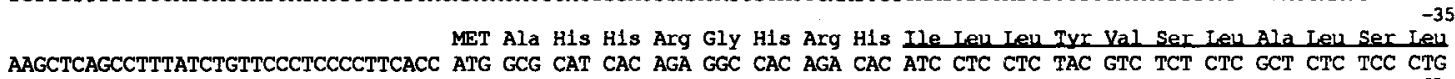
$-3-1$ Gly Leu Ala Leu Ala Glu Asp Ala Thr Asp Pro Ser Asp Asp Thr Gly Ser phe Asp Asp Val Glu Ala Val Ser Glu Glu Ala Asp GGG CTG GCC CTG GCG GAG GAC GCA ACT GAC CCC AGT GAC GAC ACC GGC AGC TTT GAT GAC GTA GAA GCG GTC AGT GAG GAA GCG GAT $\uparrow$

50

Duocelin D

Leu Asp Pro Tyr Ser Met Ser Gln Glu Leu Asn Lye hap Pro Asn Val Asp Pro Tyr Ser Tyr Leu Pro Ser Val Gly Lua ano CTG GAC CCT TAC AGC ATG TCT CAG GAA CTG AAC 20 nod CCA AAC GTT GAC CCG TAC TCA TAC CTC CCG AGT GTA GGG MAM ACA

I. $\quad \mathbf{F} 100$

100 Gly Leu Gly rum GCT TTT GAT CAC TAC GGC TTT ACT GGA GGT CTC GGC wo Aos an ATC GAC CAT TTT GGA T"TT GTT GGG GGA CTT GGC MAe AGA

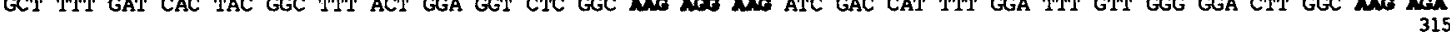
Gin Ile Asp Pro Leu Gly Phe Ser Gly Gly Ile Gly Iuana Tyr Asp Ser phe Ala Tyr Ser Ala Gly Leu Gly Iynang CAA ATT GAC CCT TTA GGA TTT TCT GGG GGT ATC GGG Na Mag TAC GAC TCT TTT GCC TAC TCT GCT GGA CTC GGA NMA CGa $\lambda 1 \quad 12 \quad 150$ Gly Met Asp Ser Leu Ala Phe Ser Gly Gly Leu Gly Iys Am Gly Met Asp Ser Leu Ala Phe Ser Gly Gly Leu Gly Iys Ano GGA ATG GAC AGT TTA GCA TTT TCG GGT GGC CTC GGA MAG MGA GGA ATG GAC AGT TTA GCA TTT TCG GGT GGC CTC GGA NAO AGA $\mathbf{\lambda 3} \mathbf{M}$ Gly Met Asp Ser Leu Ala phe Ser Gly Gly Leu Gly Ius Ang Gly Met Asp Ser Leu Ala Phe Ser Gly Gly Leu Gly Ius Axo

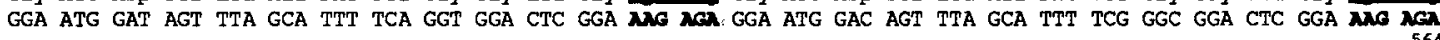
M5 GGA ATG GAT AGT TTA GCA TTT TCA GGT GGC CTC GGA AAG Man GGA ATG GAC AGT TTA GCA TTT TCA GGT GGA CTC GGA MAa MeA I J1 648 Gly Met Asp Ser Phe Thr Phe Ala Pro Gly Leu Gly Lye Ang Gly Met Asp Ser Leu Ala Phe Ala Gly Gly Leu Gly Iya Ama GGA ATG GAT AGT TTT ACG TTC GCC CCT GGT CTA GGA Na CGI GGT ATG GAT AGT CTA GCG TTC GCA GGT GGA CTG GGA AMA CGG 250 Met Asp Gly Phe Ala Phe Ala Pro Gly Leu Gly Lys and Met Asp Ser Phe Ala Phe Ala Pro Gly Leu Gly Lya Axd ATG GAC GGC TTT GCT TTT GCT CCA GGC CTT GGG NAX CGA ATG GAC AGT TTT GCT TTT GCA CCT GGT CTG GGT גAM AGA J2 I2.

Gly Met Asp Ser Leu Ala Phe Ala Gly Gly Leu Gly Luang Met Asp Ser Phe Ala Phe Ala Prj Gly Leu Gly Iya Axp

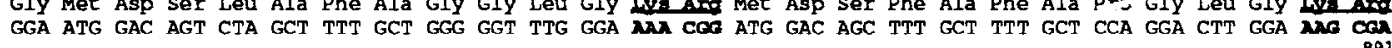
Met Asp Ser phe Ala Phe Ala Pro Gly Leu Gly Iys ang Gly Leu Asp Arg Tyr Gly Phe Val Gly Gly Leu Gly Iva Ax

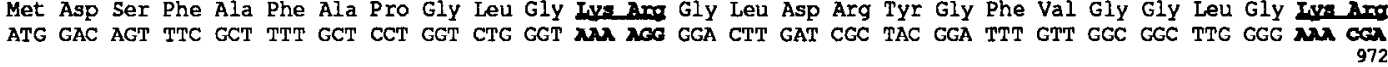
$\mathbf{n}$ BGPXP $\mathrm{A}$

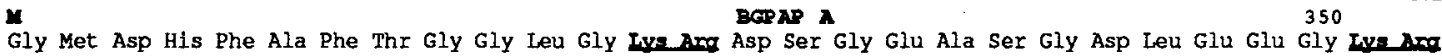
GGG ATG GAT CAT TTC GCT TTT ACT GGA GGA CTC GGC NAC AOC GAC TCG GGC GAG GCC TCG GGA GAC CTC GAG GAA GGG MAG AGA $\mathbf{I}$ $\mathbf{B 2}$ Gly Leu Asp Ala Tyr Ser Phe Thr Gly Ala Leu Gly Lys Ang GIy Leu Asp Arg Tyr Gly Phe Val Gly Gly Leu Gly Lys Ang
GGT TTG GAT GCC TAC AGC TTT ACC GGA GCT CTG GGG NA AGA GGG TTA GAT CGG TAC GGA TTC GTT GGA GGC CTC GGC NAג CGA GGT TTG GAT GCC TAC AGC TTT ACC GGA GCT CTG GGG NA NGA GGG TTA GAT CGG TAC GGA TTC GTT GGA GGC CTC GGC NAM CGA Gly Met Asp Asp Phe Ala Phe Ser Pro Gly Leu Gly Lws Lva Arg Met Asp Ser Phe Met Phe Gly Ser Arg Leu Gly Ima Amo

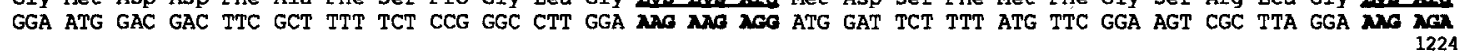
Gly Met Asp Arg phe Ser Phe Ser Gly His Leu Gly Lus amg iug Met R GGG ATG GAC AGA TTT AGT TTT TCC GGC CAC TTA GGA גa nac Na ATG GAT CAG TTT TCT TTT GGA CCG GGT CTC GGC AMa Can C1 $450 \quad \mathbf{C 2}$

Gly Phe Asp His Tyr Gly Phe Thr Gly Gly Ile Gly Lus And Gly Phe Asp His Tyx Gly Phe Thr Gly Gly Ile Gly Ius and GGG TTC GAC CAC TAC GGC TTT ACG GGC GGC ATC GGC NAG CEN GGG TTC GAC CAC TAC GGC TTT ACG GGC GGC ATC GGC MAG CGA

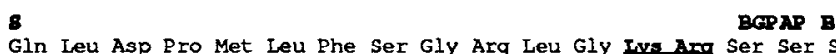

BGPAP $\mathrm{B}$ Gin Leu Asp Pro Met Leu Phe Ser Gly Arg Leu Gly Ius ang Ser Ser Ser Glu Gln Glu Glu Glu Asp Val Arg Gin Val Glu CAG TTG GAT CCC ATG TTG TTT TCT GGT CGT CTG GGA $\lambda$ A $\lambda$ A AGT AGC AGC GAA CAG GAG GAG GAG GAT GTG AGG CAG GTG GAG 500

Iun Ser Thr Thr Glu Glu Gln Ser Ser Lys Ser Phe * Na neg TCA ACG ACA GAG GAA CAG TCG TCG AAG AGC TTG TGA GAGTGACCGCTGTGACGTAGTATCCCGCCTGATGGCCAGGGAGACAGGCGTGTGTGC GGGCAGAGACATCGAGAGACCAGGCCACTCCCTCTTCTCCTCTGTCTGTCTAGAGATACTCGNXTNAXCGGTTCCCCTCCPCCACAAGGAAAAGTGAAGGGAGT"TCTTTTCAG TTTGTGACTTTTGCTGGCTCTTGTGTGCAATGATATCCTGGACATTACTTGCTAGATCTAGCCCCTCTGTTGTTGAAACTGCCTGTCGAATGAAATGAAAATCTTTTGAGAGCA CACACGTATTGTTTTGGCTTGTTATAATNUTAAAGAAAACGGTTGAAGATTCTAATGCTCATTTCATTCACGTAAATTTGGAGACGAGTTCAGTGCGAGATGAAAGGAATGT GTTTGCTGGTTTGTTTGTAGACACACGCGCATATACATACATACATAAACACACACGCACACGCACACACACACACACACACACACACACA

Figure 3. Nucleotide sequence of a clone (pBU13) isolated from an Aplysia cDNA nervous system library. The predicted amino acid sequence of the buccalin precursor is shown above the nucleic acid sequence. Numbers above and below the sequence denote amino acid and nucleotide positions, respectively, assigned relative to the initiator methionine residue (MET). Eleven consecutive amino acids that may form the hydrophobic domain of a signal peptide are underlined. The proposed site of signal peptidase cleavage is denoted by a arrow below the sequence. Di- and tribasic potential sites of endopeptidase cleavage are shown in underlined boldface. Boldface letters above the amino acid sequence refer to peptides that could potentially be cleaved from the precursor (tabulated in Fig. 4). With the exceptions of peptides that were previously identified (buccalins $A$, $\mathrm{B}$, and $\mathrm{C}$ ), the buccalin-related peptides are designated in the order of their position on the precursor. The stop codon is denoted by an asterisk, and consensus polyadenylation signal sequences are in boldface. The site of polyadenylation of a second clone (pBU01, Fig. 2) is underlined. BGPAP, Buccalin gene-predicted acidic peptide. 
Buccalin-related Peptides

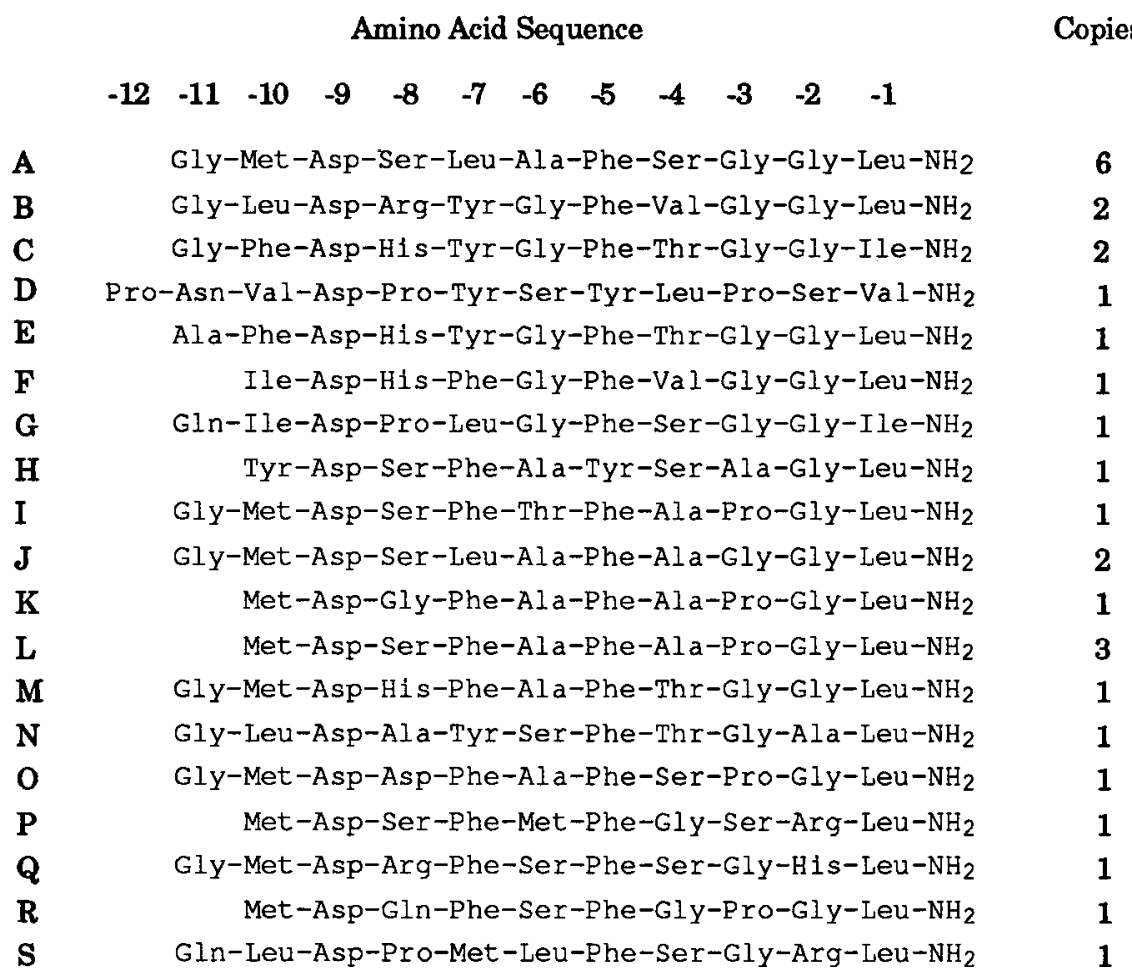

B

\section{Buccalin Gene Predicted Acidic Peptides}

\section{Copies}

Figure 4. Peptides encoded by the buccalin precursor polypeptide. $A$, Tabulation of peptide sequences and copy numbers present on the buccalin precursor protein. Designation of peptides corresponds to Figure 3 . The glycine residues present at the carboxyl end of each peptide in the precursor are postulated to contribute to amidation. Peptides are aligned and amino acid positions are assigned relative to the carboxyl terminus. Note that the only residue that is invariant throughout all of these peptides is the aspartate in the -9 position. $B$, Amino acid sequences of the BGPAPs. These two peptides are flanked by dibasic cleavage sites in the buccalin precursor. The amide group at the carboxyl end of BGPAP A is proposed to result from cleavage of a glycine residue present in the precursor. a central hydrophobic H-region (von Heijne, 1988). The presence of a glycine residue at position 21 of the buccalin prepropolypeptide (Fig. 3, asterisk) is in agreement with a common pattern in which a glycine defines the border between the central h-region and the carboxy-terminal C-region of signal peptides. In eukaryotes, this glycine residue typically occurs in the -5 position with respect to signal peptidase cleavage. We have therefore tentatively assigned the site of cleavage in the buccalin prepropolypeptide following the alanine in position 25 (Fig. 3, arrow). This proposed signal peptidase cleavage site conforms to the " $(-3,-1)$ " rule (von Heijne, 1986), since these positions are both occupied by small apolar alanine residues (Fig. 3, denoted -3 and -1 above amino acid sequence).

The proposed signal peptide cleavage site is followed by an acidic sequence in which aspartic and glutamic acid residues account for 13 of 35 positions. Such negatively charged regions, commonly found in polypeptide precursors, may provide charge neutralization offsetting the predominance of basic residues in the segments containing peptides (Schaefer et al., 1985). Following this acidic region, the precursor assumes its predominant structure consisting of contiguous buccalin-related peptides flanked by di- or tribasic endoproteolytic cleavage sites (Fig. 3, boldface). The Lys-Arg basic pair predominates, accounting for 29 of 32 potential cleavage sites. The remaining three are tribasic, including two Lys-Arg-Lys sites and one Lys-Lys-Arg. Cleavage at tribasic residues has been demonstrated in the egglaying hormone precursor of Aplysia (Newcomb and Scheller, 1987). A glycine residue precedes each potential cleavage site. This glycine is likely to act as a nitrogen atom donor in the formation of an $\alpha$-amide group at the carboxyl terminus of each peptide (Bradbury and Smyth, 1991). Amidation of the buccalin-related peptides is required for bioactivity (Cropper et al., 1988; Weiss et al., 1988).

Nineteen distinct peptides with buccalin-like sequence homology are present on the precursor (tabulated in Fig. 4.4); included are buccalins $\mathrm{A}, \mathrm{B}$, and $\mathrm{C}$, the three peptides that have been biochemically purified (Cropper et al., 1988; Weiss et al., 1988). The remaining 16 buccalin-related peptides have been designated buccalin $\mathrm{D}$ through buccalin $\mathrm{S}$ in the order of their appearance on the precursor. Assuming that the glycine residue located at the carboxyl terminus of each peptide contributes to its amidation, 12 of the buccalin-related peptides are 11 amino acids in length, 6 are 10 amino acids, and 1 (buccalin D) is 12 amino acids long. For comparison, the peptides were aligned 


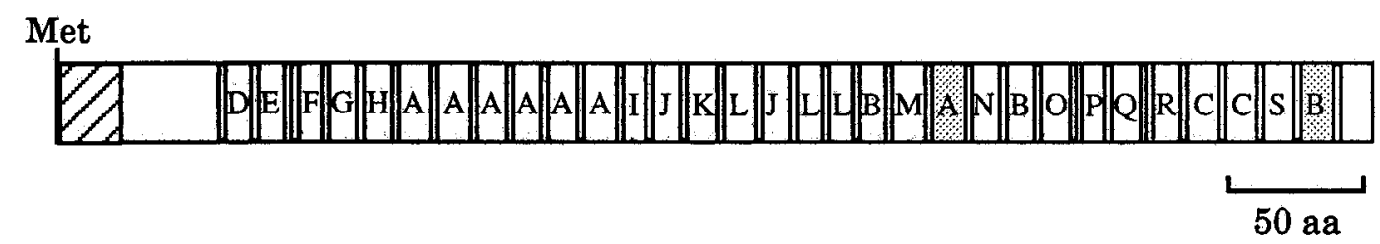

Figure 5. Organization of the buccalin precursor polypeptide. Hatched region represents the proposed signal peptide, and the BGPAPs are stippled. Vertical lines denote di- and tribasic cleavage sites. Note that the six copies of buccalin A are contiguous while copies of other peptides (e.g., buccalin $\mathrm{L}$ and buccalin B) are separated on the precursor.

and amino acid positions assigned relative to their carboxy termini (Fig. 4A). The only residue that is invariant throughout the buccalin family is the aspartic acid in the -9 position. Substitutions at some positions appear to be conservative, maintaining the hydrophobicity of positions $-1,-5,-7$, and -10 and the presence of an aromatic residue in position $-5 . \Lambda \mathrm{t}$ other positions, amino acid substitutions are less restricted, for example, position -8 , in which nine different amino acids occur, including the positively charged arginine (buccalin $\mathrm{B}$ and Q) and the negatively charged aspartic acid (buccalin $\mathrm{O}$ ).

The buccalin-related peptides are present in varying copy numbers on the precursor (Fig. $4 A$ ). The majority (14) of the

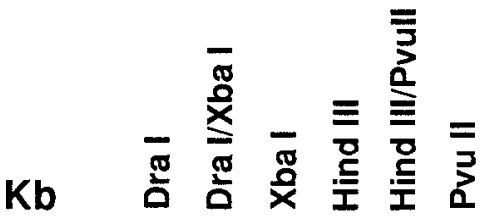

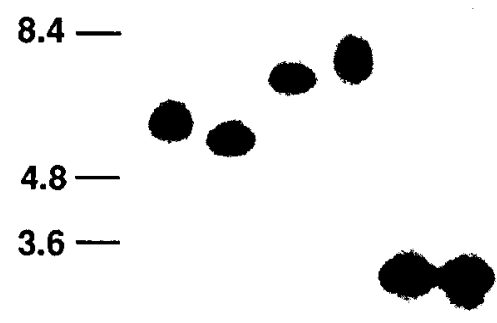

$2.3-$ peptides occur in a single copy, but three (buccalin B, C, and J) are present in two copies, one (buccalin L) occurs in three copies, and one (buccalin A) is found in six copies. Up to 29 buccalinrelated peptides can therefore potentially be cleaved from each precursor polypeptide. Some of the peptides that are present in multiple copies, for example, the six copies of buccalin A, are positioned contiguously on the precursor (Fig. 5). Others, for example, the two copies of buccalin $J$, are separated by intervening peptides. The nucleotide sequences specifying particular amino acids in the peptides that are present in multiple copies exhibit varying degrees of homology. For example, the two copies of buccalin $\mathrm{C}$ are encoded by identical nucleotide sequences. The sequence encoding the six copies of buccalin $\mathrm{A}$ is also well conserved, with differences in codons occurring only in the wobble position of two glycine residues (amino acid positions -3 and -4 ) and one serine (amino acid -5). In contrast, in the two copies of buccalin $\mathrm{B}$ the codons for the leucine residues in the -2 position (TTG and CTC) and -11 position (CTT and TTA) are less conserved.

Two additional peptides on the buccalin precursor are flanked by dibasic cleavage sites. These peptides do not share sequence similarity with the buccalin-related peptides. They arc both rich in acidic residues and have therefore been designated the buccalin gene-predicted acidic peptides (BGPAPs; Fig. $4 B$ ). One of these peptides (BGPAP A) is flanked by buccalin-related peptides, while one (BGPAP B) is located near the carboxyl terminus of the precursor (Fig. 5). If the BGPAPs are subjected to further posttranslational processing following cleavage, the glycine residue at the carboxyl end of BGPAP A is likely to act as a nitrogen donor to an amide group.

\section{Organization of the buccalin gene}

In order to determine the number of buccalin genes present in the Aplysia genome, DNA was isolated from the ovotestis of a single specimen and digested with individual restriction endonucleases or enzyme pairs (Fig. 6). No restriction sites for the enzymes used in these experiments are present in the known sequence of the buccalin gene. Digested DNA was blotted and probed with a $1.2 \mathrm{~kb}$ buccalin clone (Fig. 2, pBU12). A single hybridizing band was observed with each enzyme or pair, indicating that the buccalin gene is present in a single copy in the genome of Aplysia.

Single-copy genes of invertebrates are known to exhibit substantial sequence polymorphism among individuals (Britten et al., 1978). In order to examine one source of such polymorphism, allelic variation, in the region of the buccalin gene, genomic DNA isolated from three specimens was digested with $E c o$ RI and $N c o I$ and probed with the insert from pBU12 (Fig. $7 A$ ). The pattern of hybridization obtained, in which single hybridizing bands occurred in some individuals (e.g., lanes $\mathrm{G} 2$ in
Fig. $7 A$ ) while doublet bands were present in others (lanes G3),
Figure 6. Southern analysis of the buccalin gene. $A$, Genomic DNA $(10 \mu \mathrm{g} /$ lane) was isolated from the ovotestis of a single Aplysia specimen. The DNA was digested to completion with the restriction enzymes or pairs shown for each lane, fractionated on a $0.75 \%$ agarose gel, denatured, blotted onto nitrocellulose, and hybridized to a buccalin clone (pBU12) ${ }^{32} \mathrm{P}$-labeled by nick translation. One hybridizing band was observed with each digest, indicating that this gene is present in a single copy in the Aplysia genome. The size standard was a BstEII digest of wild-type bacteriophage $\lambda$ DNA. 
A

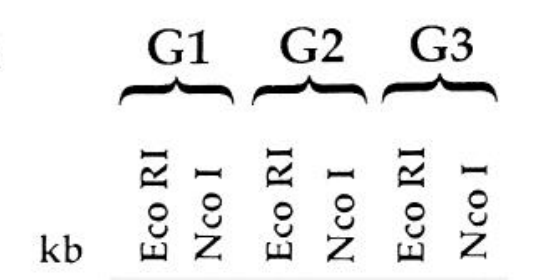

$9.4-$

$6.6-$

$4.4-$

$\cos (20)$

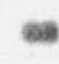

tow

$2.3-$
Figure 7. Southern analyses of the buccalin gene polymorphism and organization. $A$, Genomic DNA $(10 \mu \mathrm{g})$ lane) from three Aplysia specimens ( $G 1$, $G 2$, and $G 3$ ) was digested to completion with $E c o$ RI or $N c o$ I, fractionated on an agarose gel, transferred, and probed with the $1.2 \mathrm{~kb}$ insert from buccalin clone pBU12 (see Fig. 2) labeled by random priming. Hybridization to doublet bands in the blots of some individuals and single bands in others indicates that an insert is present in the region of one buccalin allele. The size standard was a Hind III digest of bacteriophage $\lambda$ DNA. $B$, Genomic DNA (10 $\mu \mathrm{g} /$ lane) isolated from the ovotestis of a single Aplysia was digested with $N c O \mathrm{I}, \mathrm{Bg} / \mathrm{II}$, or both enzymes. The DNA was fractionated on an agarose gel, transferred, and probed with an approximately 1.8 kb NcoI-Bg/II fragment of pBU13 (see Fig. 2) labeled by nick translation. Hybridization of this probe to a band $\sim 2.8$ $\mathrm{kb}$ in length (middle lane) indicates that there is approximately $1 \mathrm{~kb}$ of intervening sequence between these two restriction sites in the buccalin gene. Hybridization to bands in DNA digested with individual enzymes (flanking lanes) demonstrates the efficacy of each digestion. The size standard was a BstEII digest of bacteriophage $\lambda$ DNA. indicates that an insert is present on one allele of the buccalin gene (cf. Scheller et al., 1982; Nambu et al., 1983).

The organization of the buccalin gene was further examined by using a fragment of known length $(\sim 1.8 \mathrm{~kb} \mathrm{NcoI}-B g / \mathrm{II}$ fragment of pBU13; see Fig. 2) to probe digested genomic DNA. This probe hybridized to a band $\sim 2.8 \mathrm{~kb}$ in length when the genomic DNA was digested with $\mathrm{NcoI}$ and $\mathrm{Bg} / \mathrm{II}$ (Fig. $7 \mathrm{~B}$, middle lane), suggesting that approximately $1 \mathrm{~kb}$ of intervening sequence is present in the buccalin gene between these two restriction sites. Preliminary PCR experiments (not shown), in which genomic DNA was amplified with specific pairs of oligonucleotide primers, indicate that an intron is present toward the $3^{\prime}$ end of the coding region of the gene, in the region between the Bam HI site and the termination codon.

\section{Buccalin gene expression}

The general tissue distribution of buccalin gene expression was examined using a protocol for reverse transcription of RNA and PCR amplification of cDNA. RNA isolated from Aplysia CNS, ovotestis, and heart was reverse transcribed and amplified using PCR5 and MM025 oligonucleotides (Fig. 2) as primers. Following agarose gel fractionation, a single product (approximately $1400 \mathrm{bp}$ in length) was detected in the nervous system lane. Probing a blot with an internal oligonucleotide (BUC30, Fig. 2) confirmed that this product represents amplified buccalin cDNA (Fig. 8A, lane NS). No products were detected in the ovotestis or heart cDNA (Fig. $8 A$, lanes $O V$ and $H T$ ), indicating that expression of the buccalin gene does not occur in these tissues.

RNA in situ hybridization experiments were used to localize the expression of the buccalin gene in the Aplysia CNS. A 390 nucleotide antisense probe (Fig. 2, pBU03) was hybridized with $20 \mu \mathrm{m}$ sections of the ring ganglia. Hybridization was observed in a small subset of neurons and in a few cell clusters in the cerebral and pedal ganglia (Fig. $8 B$; cf. Miller et al., 1992). Expression of the buccalin mRNA was particularly abundant in the cytoplasmic region of the neuronal cell bodies.

\section{Discussion}

The generation of diversity in the buccalin neuropeptide family The buccalin-related peptides represent an example of the most fundamental classification of peptide relatedness, the intragene family, in which a set of peptides with similar sequences are derived from a single precursor encoded by a single gene (Price et al., 1987). Although several neuropeptide precursors in Aplysia contain multiple related peptides (e.g., Scheller et al., 1983; Taussig and Scheller, 1986; Miller et al., 1993), the 19 related peptides on this buccalin precursor constitute the largest such family characterized to date. Recent reports (Kobayashi and Muneoka, 1990; Moffett, 1990) indicate that the buccalins belong to a larger intraphyletic peptide family (Price et al., 1987). However, since the buccalin gene of Aplysia described in this study is the first to be studied, little is presently known concerning the extent of the variety and distribution of these peptides in mollusks.

Neuropeptide diversity is generated, in part, from the flexibility of gene organization and expression (Scheller et al., 1982; Buck et al., 1987; Sessin et al., 1989). The diversity of the buccalin-related peptides may have arisen via multiple intragenic unequal crossing-over events (see Sharp and Li, 1987). The resulting iterative precursor structure resembles the organization of the precursors for the neuropeptide FMRFamide that have been characterized in Aplysia (Schaefer et al., 1985; Taussig and Scheller, 1986), the pond snail Lymnaea stagnalis (Linacre et al., 1990), Drosophila (Nambu et al., 1988; Schneider and Taghert, 1988), and Caenorhabditis elegans (Rosoff et al., 1992). Elongation with repeating peptide units may confer sev- 


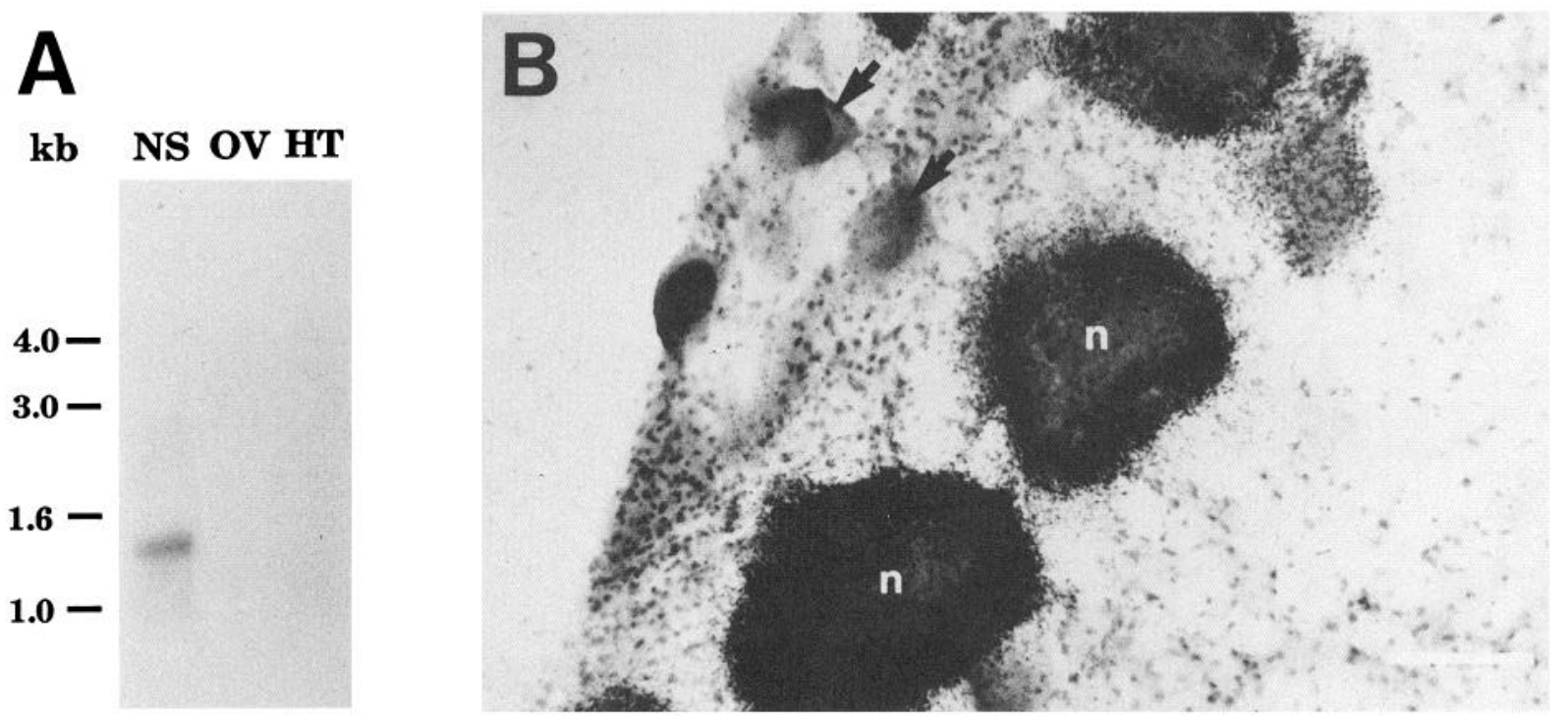

Figure 8. Expression of the buccalin precursor mRNA. A, Reverse transcription/PCR analysis of buccalin gene expression. Aplysia RNA isolated from the nervous system $(N S)$, ovotestis $(O V)$, and heart $(H T)$ was reverse transcribed, and the resulting cDNA was amplified using the oligonucleotides BUPCR5 and MM025 (see Fig. 2) as primers. Amplification products were fractionated on an agarose gel, transferred to nitrocellulose, and probed with an internal oligonucleotide (BUC30, Fig. 2) end-labeled with polynucleotide kinase. A single hybridizing band, approximately 1.4 $\mathrm{kb}$ in length, is present in the $N S$ lane only, indicating that buccalin gene expression is tissue specific. $B$, In situ hybridization of a ${ }^{35} \mathrm{~S}$-labeled RNA antisense probe generated from a $390 \mathrm{bp}$ subcloned EcoRI-XhoI fragment (pBU03 in Fig. 2) from the coding region of the buccalin cDNA (corresponding to the bases 649-1039 of Fig. 3). Single-stranded RNA probes were produced using T3 (antisense) or T7 (sense) RNA polymerase in transcription reactions with linearized templates, following standard protocols (Promega). Sections ( $20 \mu \mathrm{m})$ of the ring ganglia were collected on silanated slides (Clayton and Alvarez-Buylla, 1989), cross-linked using UV light (Tiedge, 1991), treated with proteinase K (10 $\mu \mathrm{g} / \mathrm{ml}, 5 \mathrm{~min}$ ), and subjected to postfixation (4\% paraformaldehyde, $5 \mathrm{~min})$. Prehybridization $(1-2 \mathrm{hr})$ and hybridization $\left(3-5 \times 10^{6} \mathrm{cpm} / \mathrm{ml}\right.$ of probe, $\left.12-18 \mathrm{hr}\right)$ were carried out at $50^{\circ} \mathrm{C}$. Bright-field image (antisense probe) shows the presence of autoradiographic signal (black grains) over neuronal somata in the pedal ganglion. Cell nuclei $(n)$ are hematoxylin counterstained. Arrows indicate neurons in which hybridization did not occur. No specific signal was observed with the sense RNA probe. Scale bar, $100 \mu \mathrm{m}$.

eral advantages to a peptide precursor. The production of multiple copies of a particular peptide (e.g., the six copies of buccalin A) from each precursor polypeptide could serve to increase the quantity of that peptide that can be stored in a vesicle (Schaefer et al., 1985). The presence of multiple related peptides on such a precursor may ensure the co-release of a specific complement of peptides that differ in their susceptibility to proteolysis or in their efficacy as agonists, but that are all required for complete receptor activation (see below).

In contrast to the Aplysia and Lymnaea FMRFamide precursors, where the repeating units consist of a peptide copy and an acidic spacer peptide, the contiguous arrangement of the buccalin-related peptides indicates that the most basic repeat unit consists of a peptide (10-12 amino acids) plus a Gly-LysArg sequence. It has been proposed that acidic spacer regions could provide neutralization for the positively charged peptides and cleavage sites and may aid in packaging precursor products in the secretory granule (Schaefer et al., 1985; Scheller and Kirk, 1987). The contiguity of the peptides in the buccalin precursor resembles the arrangement of the FMRFamide precursor in Drosophila and an exon that encodes two N-terminal-extended FMRFamide-like peptides in Lymnaea (Saunders et al., 1991). Interestingly, in the precursors that do not contain repeating acidic sequences, there are regions (e.g., the 35 amino acids following the signal sequence of the buccalin precursor, and the BGPAPs) that are rich in acidic residues.

\section{Cotransmitter diversity and neuronal signaling}

The combination of cotransmitters with classical neurotransmitters serves to increase substantially the potential information content of synapses (Burnstock, 1985; Hökfelt, 1987; Kupfermann, 1991). Buccalin-related peptides have been localized to both of the buccal cholinergic motor neurons (B15 and B16) that innervate the ARC muscle (Cropper et al., 1988, 1990b; Weiss et al., 1988; Church and Lloyd, 1991). The buccalins that have been most completely assessed for bioactivity (buccalins $\mathrm{A}$ and $\mathrm{B}$ ) reduce evoked ARC contractions, and it has been proposed that they act presynaptically to decrease the release of ACh (Cropper et al., 1988, 1990a).

The proposed mechanism of action of the buccalin-related peptides in $\mathrm{B} 15$ and $\mathrm{B} 16$ requires that the neurons that produce these peptides also produce buccalin receptors that are positioned at or near their synaptic terminals. The presynaptic buccalin receptors may mediate both homosynaptic regulation of $\mathrm{ACh}$ release and/or heterosynaptic interactions between B15 and B16. It is possible that different variants of the buccalinrelated peptides could execute each of these actions, depending upon their differential susceptibility to proteolysis. Although presynaptic cholinergic receptors have been shown to mediate both increases and decreases of central synaptic transmission at neuro-neuronal synapses in the buccal ganglion of Aplysia (Baux and Tauc, 1987; Fossier et al., 1988), the role of ACh in heterosynaptic interactions at the ARC muscle could be limited due to effective hydrolysis by cholinesterases (Cohen et al., 1978; but see Lloyd, 1991). If buccalin-related peptides are able to diffuse between the terminals of B15 and B16 (see Jan and Jan, $1982,1983)$, then they may play a role in heterosynaptic control of $\mathrm{ACh}$ release.

The degree to which the large number of related peptides present on the buccalin precursor provides flexibility or preci- 
sion of signaling will depend upon the specificity exhibited by the receptors in the systems at which they act. In the ARC neuromuscular system, buccalin B is two to three times as potent as buccalin $\mathrm{A}$ in reducing neuron-evoked contractions (Weiss et al., 1988). Similarities of structure suggest that the different buccalin-related peptides could act as partial agonists for a nonselective receptor, with the overall response reflecting their summed efficacies and stoichiometry. This seems to be the case for the actions of FMRFamide-related peptides on neurosecretory cells in Lymnaea (Brussaard et al., 1988, 1989) and on cardiac receptors in Helix and Lymnaea (Price, 1986; Buckett et al., 1990), where structure-activity and cross-desensitization experiments have identified receptors that respond to multiple family members. The presence of multiple peptides and copies, coupled with this type of nonselective receptor, could simply provide an advantageous redundancy to the system.

Alternatively, receptors may be present that are finely tuned to peptide variation (see Kemenes et al., 1992). For example, two classes of receptors on neurons in the snail Helix are differentially sensitive to FMRFamide and native N-terminal-extended heptapeptides (Cottrell and Davies, 1987; Payza, 1987). In what may represent an extreme example of peptide receptor specificity, autoexcitatory responses of a cluster of neurosecretory cells in Lymnaea require the simultaneous presence of four different peptides, three of which have very similar structures (Ter Maat et al., 1988; Vreugdenhil et al., 1988; see also Rothman et al., 1983). If any one of these peptides is omitted from the applicd solution, responscs cannot bc elicitcd by increasing the concentration of the remaining related peptides (Brussaard et al., 1991). In light of such apparent potential for peptide receptor specificity, it would be interesting to compare the structure-activity profiles of the buccalin receptors on identified neurons in Aplysia (Alevizos et al., 1989; Raymond et al., 1989; Rosen et al., 1989).

Clearly, genetic mechanisms for producing related neuropeptides and multiple peptide copies provide neuronal systems with considerable potential for generating complex, redundant, and specific forms of signaling. The presence of the large family of buccalin-related cotransmitters within well-defined neural circuits in Aplysia may provide favorable systems in which these mechanisms can be further studied.

\section{References}

Adams ME, O'Shea M (1983) Peptide cotransmitter at a neuromuscular junction. Science 221:286-288.

Alevizos A, Weiss KR, Koester J (1989) SCP-containing R20 neurons modulate respiratory pumping in Aplysia. J Neurosci 9:3058-3071.

Angerer LM, Stoler MH, Angerer RC (1987) In situ hybridization with RNA probes: an annotated recipe. In: In situ hybridization (Valentino KL, Eberwine JH, Barchas JD, eds), pp 43-70. New York: Oxford UP.

Baux G, Tauc L (1987) Presynaptic actions of curare and atropine on quantal acetylcholine release at a central synapse of Aplysia. J Physiol (Lond) 388:665-680.

Bcushausen S, Bergold P, Sturner S, Elste A, Roytenberg V, Schwartz JH, Bayley H (1988) Two catalytic subunits of cAMP-dependent protein kinase generated by alternative RNA splicing are expressed in Aplysia neurons. Neuron 1:853-864.

Bishop CA, Wine JJ, O'Shea M (1984) Neuropeptide proctolin in postural motoneurones of the crayfish. J Neurosci 4:2001-2009.

Bishop CA, Wine JJ, Nagy F, O'Shea MR (1987) Physiological consequences of a peptide cotransmitter in a crayfish nerve-muscle preparation. J Neurosci 7:1769-1779.
Blobel G, Dobberstein B (1975) Transfer of proteins across membranes. I. Presence of proteolytically processed and unprocessed nascent immunoglobulin light chains on membrane-bound ribosomes of murine myeloma. J Cell Biol 67:835-851.

Bradbury AF, Smyth DG (1991) Peptide amidation. Trends Biochem Sci 16:112-115.

Britten RJ, Cetta A, Davidson EH (1978) The single-copy DNA sequence polymorphism of the sea urchin Strongylocentrotus purpuratus. Cell 15:1175-1186.

Brosius J (1989) Superpolylinkers in cloning and expression vectors. DNA 8:759-777.

Brussaard AB, Kits KS, Ter Maat A, Van Minnen J, Moed PJ (1988) Dual inhibitory action of FMRFamide on neurosecretory cells controlling egg laying behavior in the pond snail. Brain Res 447:35-51.

Brussaard AB, Kits KS, Ter Maat A (1989) One receptor type mediates two independent effects of FMRFa on neurosecretory cells of Lymnaea. Peptides 10:289-297.

Brussaard AB, Schluter NCM, Ebberink RHM, Kits KS, Ter Maat A (1991) Discharge induction in molluscan peptidergic cells requires a specific set of autoexcitatory neuropeptides. Neuroscience 39:479491.

Buck LB, Bigelow JM, Axel R (1987) Alternative splicing in individual Aplysia neurons generates neuropeptide diversity. Cell 51:127-133.

Buckett KJ, Dockray GJ, Osborne NN, Benjamin PR (1990) Pharmacology of the myogenic heart of the pond snail Lymnaea stagnalis. J Neurophysiol 63:1413-1425.

Burnstock $G$ (1985) The changing face of autonomic neurotransmission. Acta Physiol Scand 126:67-91.

Calabrese RL (1989) Modulation of muscle and neuromuscular junctions in invertebrates. Semin Neurosci 1:25-34.

Campbell G (1987) Cotransmission. Annu Rev Pharmacol Toxicol 27:51-70.

Church PJ, Lloyd PE (1991) Expression of diverse neuropeptide cotransmitters by identified motor neurons in Aplysia. J Neurosci 11: 618-625.

Clayton DF, Alvarez-Buylla A (1989) In situ hybridization using PEGembedded tissue and riboprobes: increased cellular detail coupled with high sensitivity. J Histochem Cytochem 37:389-393.

Cohen J, Weiss KR, Kupfermann I (1978) Motor control of buccal muscles in Aplysia. J Neurophysiol 41:157-180.

Cottrell GA, Davies NW (1987) Multiple receptor sites for a molluscan peptide (FMRFamide) and related peptides of Helix. J Physiol (Lond) 382:51-68.

Cropper EC, Lloyd PE, Reed W, Tenenbaum R, Kupfermann I, Weiss KR (1987a) Multiple neuropeptides in cholinergic motor neurons of Aplysia: evidence for modulation intrinsic to the motor circuit. Proc Natl Acad Sci USA 84:3486-3490.

Cropper EC, Tenenbaum R, Kulks MAG, Kupfermann I, Weiss KR (1987b) Myomodulin: a bioactive neuropeptide present in an identified cholinergic buccal motor neuron of Aplysia. Proc Natl Acad Sci USA 84:5483-5486.

Cropper EC, Miller MW, Tenenbaum R, Kolks MAG, Kupfermann I, Weiss KR (1988) Structure and action of buccalin: a modulatory neuropeptide localized to an identified small cardioactive peptidecontaining cholinergic motor neuron of Aplysia californica. Proc Natl Acad Sci USA 85:6177-6181.

Cropper EC, Hooper SL, Kupfermann I, Weiss KR (1990a) Differential effects of buccalin on peptidergic and cholinergic components of B15-induced contractions of the ARC muscle. Soc Neurosci Abstr 16:307.

Cropper EC, Miller MW, Vilim FS, Tenenbaum R, Kupfermann I, Weiss KR (1990b) Buccalin is present in the cholinergic motor neuron B16 of Aplysia and it depresses accessory radula closer muscle contractions evoked by stimulation of B16. Brain Res 512:175-179.

Cropper EC, Vilim FS, Alevizos A, Tenenbaum R, Kolks MAG, Rosen S, Kupfermann I, Weiss KR (1991) Structure, bioactivity, and cellular localization of myomodulin B: a novel Aplysia peptide. Peptides 12:683-690.

Fossier P, Poulain B, Baux G, Tauc L (1988) Both presynaptic nicotinic-like and muscarinic-like autoreceptors regulate acetylcholine release at an identified neuro-neuronal synapse of Aplysia. Pfluegers Arch 411:345-352.

Hökfelt T (1987) Neuronal communication through multiple coexisting messengers. In: Synaptic function (Edelman GM, Gall WE, Cowan WM, eds), pp 179-211. New York: Wiley. 
Jan LY, Jan YN (1982) Peptidergic transmission in sympathetic ganglia of the frog. J Physiol (Lond) 327:219-246.

Jan YN, Jan LY (1983) Coexistence and corelease of cholinergic and peptidergic transmitters in frog sympathetic ganglia. Fed Proc 42 : 2929-2933.

Kemenes G, S-Rózsa K, Stefano G, Carpenter DO (1992) Distinct receptors for leu- and met-enkephalin on the metacerebral giant cell of Aplysia. Cell Mol Neurobiol 12:107-1 19.

Kobayashi M, Muneoka Y (1990) Structure and action of molluscan neuropeptides. Zool Sci 7:801-814.

Kozak M (1983) Compilation and analysis of sequences upstream from the translational start site in eukaryotic mRNAs. Nucleic Acids Res 12:857-872.

Kupfermann I (1991) Functional studies of cotransmission. Physiol Rev 71:683-732.

Linacre A, Kellett E, Saunders S, Bright K, Benjamin PR, Burke JF (1990) Cardioactive neuropeptide Phe-Met-Arg-Phe-NH (FMRFamide) and novel related peptides are encoded in multiple copies by a single gene in the snail Lymnaea stagnalis. J Neurosci $10: 412-419$.

Lloyd PE (1988) Fast axonal transport of modulatory neuropeptides from central ganglia to components of the feeding system in Aplysia. J Neurosci 8:3507-3514.

Lloyd PE (1991) Absence of acetylcholinesterase (AChE) activity at cholinergic neuromuscular synapses in Aplysia. Soc Neurosci Abstr 17:1355.

Lloyd PE, Mahon AC, Kupfermann I, Cohen JL, Scheller RH, Weiss KR (1985) Biochemical and immunocytological localization of molluscan small cardioactive peptides in the nervous system of Aplysia californica. J Neurosci 5:1851-1861.

Lloyd PE, Frankfurt M, Stevens P, Kupfermann I, Weiss KR (1987) Biochemical and immunocytological localization of the neuropeptides $\mathrm{SCP}_{\mathrm{A}}, \mathrm{SCP}_{\mathrm{B}}$, and FMRFamide to neurons involved in the regulation of feeding in Aplysia. J Neurosci 7:1123-1132.

Lloyd PE, Kupfermann I, Weiss KR (1988) Central peptidergic neurons regulate gut motility in Aplysia. J Neurophysiol 59:1613-1626.

Lundberg IM, Hökfelt T (1986) Multiple co-existence of peptides and classical transmitters in peripheral autonomic and sensory neuronsfunctional and pharmacological implications. In: Progress in brain research, Vol 68, Coexistence of neuronal messengers: a new principle in chemical transmission (Hökfelt T, Fuxe K, Pernow B, eds), pp 241-262. Amsterdam: Elsevier.

Mahon AC, Lloyd PE Weiss KR, Kupfermann I, Scheller RH (1985) The small cardioactive peptides A and B of Aplysia are derived from a common precursor molecule. Proc Natl Acad Sci USA 82:39253929.

Manley JL (1988) Polyadenylation of mRNA precursors. Biochem Biophys Acta 950:1-12.

Miller MW, Cropper EC, Eisinger K, Vilim F, Tenenbaum R, Beushausen S, Brosius J, Kupfermann I, Weiss KR (1989) The buccalin neuropeptide family in Aplysia: purification of buccalin $C$ and sequence of additional peptides predicted by a cDNA clone. Soc Neurosci Abstr 15:665.

Miller MW, Alevizos A, Cropper E, Kupfermann I, Weiss KR (1992) The distribution of buccalin-like immunoreactivity in the central nervous system and peripheral tissues of Aplysia californica. J Comp Neurol 320:182-195.

Miller MW, Beushausen S, Vitek A, Stamm S, Kupfermann I, Brosius J, Weiss KR (1993) The myomodulin-related neuropeptides: characterization of a gene encoding family of peptide cotransmitters in Aplysia. J Neurosci 13:3358-3367.

Moffett SB (1990) The genital ganglion of the snail Melampus bidentatus contains neurons immunoreactive to the peptides $\alpha \mathrm{BCP}, \mathrm{SCP}_{\mathrm{B}}$, buccalin, and CARP. Soc Neurosci Abstr 16:550.

Nambu JR, Taussig R, Mahon AC, Scheller RH (1983) Gene isolation with cDNA probes from identified Aplysia neurons: neuropeptide modulators of cardiovascular physiology. Cell 35:47-56.

Nambu JR, Murphy-Erdosh C, Andrews PC, Feistner GJ, Scheller RH (1988) Isolation and characterization of a Drosophila neuropeptide gene. Neuron 4:55-61.

Newcomb R, Scheller RH (1987) Proteolytic processing of the Aplysia egg-laying hormone and R3-14 neuropeptide precursors. J Neurosci $7: 854-863$.

Ono JK (1986) Localization and identitication of neurons with cholecystokinin and gastrin-like immunoreactivity in wholemounts of Aplysia ganglia. Neuroscience 18:957-974.
Payza K (1987) FMRFamide reccptors in Helix aspersa. Peptides $8: 1065-1074$.

Price DA (1986) Evolution of a molluscan cardioregulatory neuropeptide. Ám Zool 26:1007-1015.

Price DA, Davies NW, Doble KE, Greenberg MJ (1987) The variety and distribution of the FMRFamide-related peptides in molluscs. Zool Sci 4:395-410.

Proudfoot NJ, Brownlee GG (1976) 3' Non-coding region sequences in eukaryotic messenger RNA. Nature 263:211-214.

Raymond JL, Shulman EE, Baxter DA, Cleary LJ, Byrne JH (1989) Differential effects of the peptide buccalin and serotonin on membrane currents, action potential duration, and excitability in pleural sensory neurons of Aplysia. Soc Neurosci Abstr 15:1284.

Rosen SC, Susswein AJ, Cropper EC, Weiss KR, Kupfermann I (1989) Selective modulation of spike duration by serotonin and the neuropeptides FMRFamide, $\mathrm{SCP}_{\mathrm{B}}$, buccalin and myomodulin in different classes of mechanoafferent neurons in the cerebral ganglion of $A p l y s i a$. J Neurosci 9:390-402.

Rosoff ML, Bürglin TR, Li C (1992) Alternatively spliced transcripts of the $f l p-1$ gene encode distinct FMRFamide-like peptides in Caenorhabditis elegans. J Neurosci 12:2356-2361.

Rothman BS, Mayeri E, Brown RO, Yuan P-M, Shively JE (1983) Primary structure and neuronal effects of $\alpha$-bag cell-peptide, a second candidate neurotransmitter encoded by a single gene in bag cell neurones of Aplysia. Proc Natl Acad Sci USA 80:5753-5757.

Saunders SE, Bright K, Kellett E, Benjamin PR, Burke JF (1991) Neuropeptides Gly-Asp-Pro-Phe-Leu-Arg-Phe-amide(GDPFLRFamide) and Ser-Asp-Pro-Phe-Leu-Arg-Phe-amide (SDPFLRFamide) are encoded by an exon 3 ' to Phe-Met-Arg-Phe- $\mathrm{NH}_{2}$ in the snail Lymnaea stagnalis. J Neurosci 11:740-745.

Schaefer M, Picciotto MR, Kreiner T, Kaldany R-R, Taussig R, Scheller RH (1985) Aplysia neurons express a gene encoding multiple FMRFamide neuropeptides. Cell 41:457-467.

Scheller RH, Kirk MD (1987) Neuropeptides in identified Aplysia neurons: precursor structure, biosynthesis and physiological actions. Trends Neurosci 10:46-52.

Scheller RH, Jackson JF, McAllister LB, Schwartz IH, Kandel ER, Axel R (1982) A family of genes that codes for ELH, a neuropeptide eliciting a stereotyped pattern of behavior in Aplysia. Cell 28:707719.

Scheller RH, Jackson JF, McAllister LB, Rothman BS, Mayeri E, Axel $\mathrm{R}$ (1983) A single gene encodes multiple neuropeptides mediating a stereotyped behavior. Cell 32:7-22.

Schneider LF, Taghert PH (1988) Isolation and characterization of a Drosophila gene that encodes multiple neuropeptides related to Phe-

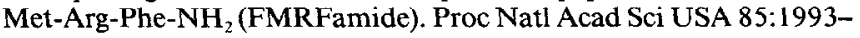
1997.

Sharp PM, Li W-H (1987) Ubiquitin genes as a paradigm of concerted evolution of tandem repeats. J Mol Evol 25:58-64.

Shymala M, Fisher JM, Scheller RH (1986) A neuropeptide precursor expressed in Aplysia neuron L5. DNA 5:203-208.

Sossin WS, Fisher JM, Scheller RH (1989) Cellular and molecular biology of neuropeptide processing and packaging. Neuron 2:14071417.

Taussig R, Scheller RH (1986) The Aplysia FMRFamide gene encodes sequences related to mammalian brain peptides. DNA 5:453-461.

Taussig R, Picciotlo MR, Scheller RH (1984) Two introns define functional domains of a neuropeptide precursor in Aplysia. In: Molecular biology of development, Vol 19 (Davidson EH, Firtel RA, eds), pp 551-560. New York: Liss.

Ter Maat A, Geraerts WPM, Jansen RF, Bos NPA (1988) Chemically mediated positive feedback generates long-lasting afterdischarge in a molluscan neuroendocrine system. Brain Res 438:77-82.

Tiedge H (1991) The use of UV light as a cross-linking agent for cells and tissue sections in in situ hybridization. DNA Cell Biol 10:143147.

Vilim FS, Kupfermann I, Weiss KR (1990) Ultrastructural localization of SCP and buccalin like immunoreactivity in the accessory radula closer muscle of Aplysia. Soc Neurosci Abstr 16:306.

Vilim FS, Price DA, Lesser W, Kupfermann I, Weiss KR (1991) Direct measurement of peptide co-transmitter release following intracellular stimulation of a single identified motorneuron in Aplysia. Soc Neurosci Abstr 17:1305.

Vilim FS, Price DA, Kupfermann 1, Weiss KR (1992) Modulation of peptide co-transmitter release from B15 neuromuscular junctions of Aplysia. Soc Neurosci Abstr 18:1104. 
von Heijne $G$ (1986) A new method for predicting signal sequence cleavage sites. Nucleic Acids Res 14:4683-4690.

von Heijne $G$ (1988) Transcending the impenetrable: how proteins come to terms with membranes. Biochem Biophys Acta 947:307333.

Vreugdenhil E, Jackson JF, Bouwmeester T, Smith AB, Van Minnen $J$, Van Heerikhuizen $H$, Klootwijk J, Joosse J (1988) Isolation, characterization and evolutionary aspects of a cDNA clone encoding multiple neuropeptides involved in the stereotyped egg-laying be- havior of the freshwater snail Lymnaea stagnalis. J Neurosci 8:4184 4191.

Weiss KR, Cropper EC, Tenenbaum R, Vilim FS, Kupfermann I (1988) Action and structure of parabuccalin-a novel neuropeptide localized to cholincrgic buccal motoncurons B15 and B16 of Aplysia. Soc Neurosci Abstr 14:177.

Wickham L, DesGroseillers L (1991) A bradykinin-like neuropeptide precursor gene is expressed in neuron L5 of Aplysia californica. DNA Cell Biol 10:249-258. 